\title{
Antifungal Activity of Essential Oils Extracted from Monodora myristica (Gaertn), Ocimum gratissimum L. and Zingiber officinalis Roscoe on Post-harvest Anthracnose of Mango Fruit (Mangifera indica L.) Variety Kent in Côte d'Ivoire
}

\author{
KOUAME Koffi Gaston¹ , KOUASSI Koffi II Nazaire², KASSI \\ Fernand Martial1, BOLOU Bi Bolou Antoine1, TUO Seydou", \\ KANKO Coffi' ${ }^{3}$, KONE Daouda ${ }^{1}$
}

${ }^{1}$ Laboratory of Plant Physiology, Faculty of Biosciences, Félix Houphouët-Boigny University, 22 PO Box 582 Abidjan 22 (Côte d'Ivoire)

${ }^{2}$ Central Laboratory of Biotechnology, National Center of Agronomic Research (LCB-CNRA), 01 PO Box 1740 Abidjan 01 (Côte-d'Ivoire)

${ }^{3}$ Laboratory of Structural Organic Chemistry, Faculty of SSMT

\begin{abstract}
This study was carried out to analyze the antifungal effect of essential oils from Monodora myristica (Gaertn) Dunal, Ocimum gratissimum L. and Zingiber officinalis (Roscoe) against Colletotrichum gloeosporioides (Penz.), the causal agent of anthracnose infecting mango fruits in Côte d'Ivoire. The inhibitory capacity of five concentrations $(100,200,500,1000$ and $2000 \mathrm{ppm})$ of each essential oil were evaluated in vitro on the mycelial growth and spore germination of $C$. gloeosporioides. The efficacy of $O$. gratissimum oil on controlling postharvest anthracnose of kent mango fruit was evaluated both before and after inoculation using mycelia discs of $C$. gloeosporioides. The $O$. gratissimum oil inhibited completely (100\%) the mycelial growth and spore germination of C. gloeosporioides at $1000 \mathrm{ppm}$ in vitro. It is fungistatic at $1000 \mathrm{ppm}$ and fungicide at $2000 \mathrm{ppm}$. The M. myristica oil showed the lowest inhibitory activity. The mango soaked into $O$. gratissimum oil concentration after inoculation yielded a highly protective effect against anthracnose disease in mango fruits at $1200 \mathrm{ppm}$. This treatment, presented the lowest infection rate $(20 \%)$ and lesion size $(0.22 \pm 0.04 \mathrm{~cm})$. Moreover, the four doses of $O$. gratissimum used, did not influence quality parameters of mango fruits. Therefore, essential oil of $O$. gratissimum could be an alternative to chemicals for control postharvest anthracnose of mangoes.
\end{abstract}

Keywords: Mango, Anthracnose, Colletotrichum gloeosporioides, essential oils, Côte d'Ivoire

\section{INTRODUCTION}

Mango (Mangifera indica L.) is one of the most tropical fruits produced in Côte d'Ivoire. It is the third export fruit after banana and pineapple. Côte d'Ivoire has been the top African mango exporting country and since 2008, it is the fifth most important world supplier of mangoes to the European market (Gerbaud, 2011). Mango is susceptible to postharvest diseases caused by various pathogenic fungi. Colletotrichum gloeosporioides (Penz) is the causal agent of anthracnose, the major postharvest disease which leads to losses of the exportation value of Côte d'Ivoire's (FIRCA, 2008). Therefore, the control of anthracnose is essential to keep and improve mango quality. Chemical methods have been and remain the main approach used to reduce losses caused by fungal parasites on many fruits (Fend and Zheng, 2007). However, repeated use of certain synthetic fungicides on packinghouses has led to the appearance of fungicide-resistant pathogens and environmental pollution (Abd-Alla and Hagga, 2010). Moreover, the use of chemical products is increasingly restricted

This article is published under the terms of the Creative Commons Attribution License 4.0 Author(s) retain the copyright of this article. Publication rights with Alkhaer Publications.

Published at: http://www.ijsciences.com/pub/issue/2015-12/

DOI: 10.18483/ijSci.869; Online ISSN: 2305-3925; Print ISSN: 2410-4477 
due to public concerns over toxic residues. Consequently, mango exportation is subjected to strict health standards and qualitative norms of import markets. Thus, it is necessary to research alternative, efficient and healthy solutions for controlling anthracnose of mangoes. The use of essential oils to control postharvest diseases of fruits is a promising approach; because, essential oils are volatile, biodegradable with short degradation periods (Sivakumar and Bautista-Baños, 2014). These qualities make them to be healthy phytosanitary products and environment abiding. In addition, they offer fewer possibilities for pathogens to develop resistant strains. Additionally, the antifungal and antibacterial properties of essential oils against many microorganisms have been well proven (Duamkhanmanee, 2008; Dikbas et al., 2009). These properties confer the advantage upon essential oils to be preferred in order to control postharvest diseases of various fruits. This study was conducted to investigate the antifungal activity of essential oils from Monodora myristica (Gaertn) Dunal, Ocimum gratissimum L. and Zingiber officinalis (Roscoe) on Colletotrichum gloeosporioides (Penz) causal agent of anthracnose of postharvest mangoes.

\section{MATERIALS AND METHODS}

\section{Essential Oils extraction}

The essential oils tested were extracted from fresh leaves of $O$. gratissimum $\mathrm{L}$, dried seeds of $M$. myristica (Gaertn) Dunal brought from Gouro market in Abidjan and rhizomes of Z. officinalis Roscoe collected in Hermankono Garo in the department of Divo (170 km Northern east of Abidjan). The essential oils were obtained by hydrodistillation of plant organs through Clevenger-type-system for 2h30min; the recovered oils were dried over anhydrous sodium sulphate and stored in darkness at $-10{ }^{\circ} \mathrm{C}$ before their use for the different tests.

\section{Isolation of fungi}

C. gloeosporioides used in this study was from mango (Mangifera indica L.) fruits of the Kent variety infected by anthracnose. The mango fruits were collected on a village plantation in the Department of Korhogo. The fungal strain was isolated from infected mango fruits by the tissue transplanting method. C. gloeosporioides was maintained on potato dextrose agar medium (PDA) and sub-cultured periodically 10 days at the pathology unit of vegetable physiology laboratory of Félix Houphouët Boigny University. The pathogens obtained were identified by microscopic examination based on the key of identification of Barnett and Hunter (1972)

Evaluation of the antifungal activity of the essential oils in vitro

The antifungal activities of the essential oils were evaluated on the radial growth of mycelia and spore germination by using agar dilution method with different concentrations.

The extracted essential oils were used at doses of 0 100, 200, 500, 1000, and 2000 ppm. The synthetic fungicide (Azoxystrombin), used as a positive control, was dissolved in sterile distilled water to get an initial solution. From this solution, dilutions were made and mixed in PDA medium to obtain 0.01, $0.05,0.1,0.5$, and $1 \mathrm{ppm}$ concentrations.

\section{Effect of essential oils on mycelial growth}

PDA was autoclaved at $121^{\circ} \mathrm{C}$, at 1 bar for $20 \mathrm{~min}$ and cooled in a water bath to $40^{\circ} \mathrm{C}$. An appropriate quantity of each essential oil or synthetic fungicide was added to a sterile melted medium, followed by manual rotation of Elernmeyer to disperse the product in the medium. The mixture was poured into $90 \mathrm{~mm}$ Petri dishes (15ml/plate). Each Petri-dish was inoculated at the centre with a mycelia disc $(5 \mathrm{~mm}$ diameter) taken at the periphery of $C$. gloeosporioides colony grown on PDA for 7 days. For each concentration of essential oils or synthetic fungicide, five Petri dishes were used. Negative control plates (without synthetic fungicide or essential oils) were inoculated following the same procedure. The plates were incubated at $28^{\circ} \mathrm{C}$ and 12/12 photoperiod for 12 days. The experiment was repeated twice. The colony diameter was measured every 24 hours following two perpendicular axes drawn at the bottom of each Petri dish which intersects at the middle of the explants. The effect of essential oil was evaluated by the percentage mycelial growth $\left(\mathrm{I}_{\mathrm{c}}\right)$ inhibition according to the following formula (Kwazou et al., 2009):

$I_{c}(\%)=[(D o-D c) / D o] \times 100$

$\mathrm{D}_{\mathrm{o}}=$ average growth of the fungus $(\mathrm{mm})$ on the control Petri dish.

$D_{c}=$ average growth of the fungus $(\mathrm{mm})$ on the Petri dish containing different concentration of each essential oil or synthetic fungicide

The explants of test plates which did not grow were transferred to dishes containing fresh PDA medium (without oil or chemical product) to assess their viability after 7 days. This procedure allowed the nature of inhibition of each product used to be determined.

\section{Effect of essential oils on spores germination}

Spores were collected from cultures grown on PDA for 14 days by pouring $10 \mathrm{ml}$ of sterile distilled water on the culture plates and scraping the plate surface with an incurved pastor pipette. The suspension of collected spores was adjusted to approximately $1.5 .10^{4}$ spores $/ \mathrm{ml}$ of distilled water. The essential oils or synthetic fungicide were directly mixed in the medium of agar culture and the mixture was poured 
into $90 \mathrm{~mm}$ Petri plates $(10 \mathrm{ml} /$ plate $)$ as above. $10 \mu \mathrm{l}$ of spore suspension were inoculated onto Petri dishes containing agar medium following two marked parallels lines under each plate in order to ease spore counting. Three repetitions were simultaneously performed by concentration. Incubation was undertaken at $28^{\circ} \mathrm{C}$, and then 200 spores per plate (100 spores per line) were examined under the microscope to determine the germination rate every 6 hours. The percentage of inhibition of spore's germination (Ig) was determined following the formula below (Bouigoumane et al., 2008):

$\operatorname{Ig}(\%)=[(\mathrm{No}-\mathrm{Nc}) / \mathrm{No}] \times 100$

No $=$ Number of germinated spores in the control Petri dish

$\mathrm{Nc}=$ number of germinated spores in the presence of a concentration of essential oil or synthetic fungicide

The effective concentration causing 50 or $90 \%$ reduction $\left(\mathrm{EC}_{50}\right.$ or $\left.\mathrm{EC}_{90}\right)$ in the mycelial growth or spores germination were determined for each product used after 7 days of mycelia growth or after 24 hours of spore germination. The results were plotted using the linear regression equation between days (in abscissa) against the rates of reduction of the mycelial growth (in ordinate) (Serghat et al., 2004).

The Minimum Inhibitory Concentration (MIC) was also determined in a parallel experiment (Remmal et al., 1993; Satrani et al., 2001). MIC was considered as the lowest concentration of the test product at which no spore germination or mycelia growth was observed.

\section{Effect of Ocimum gratissimum essential oil on the control of mango fruit anthracnose}

Fresh mango fruits cv. Kent health visibly undamaged and disease-free were used in this experiment. They had been harvested at commercial maturity from a plantation in the Department of Korhogo (Northern Côte d'Ivoire). Fruit surfaces were sterilized by soaking them in a solution of $1 \%$ sodium hypochlorite for $5 \mathrm{~min}$, rinsed with sterile distilled water, and then air dried in the culture room. A total of 50 fruits, divided into 10 lots (5 fruits per lot) were used for the test. Nine lots were wounded with a sterile needle used to make five uniform $5 \mathrm{~mm}$ deep by 0.66 -mm-diameter wounds on their peel at five distinct points for each fruit. Fruit was then inoculated by injecting $10 \mu \mathrm{l}$ of $C$. gloeosporioides spore suspension $\left(1.6 \times 10^{4}\right.$ spores $\left./ \mathrm{ml}\right)$ into each wounded point. The fruit was then submitted to treatment with $O$. gratissimum oil which was modified at previously determined in vitro $\mathrm{EC}_{50}, \mathrm{EC}_{90}$ and MIC concentrations (150; 300; 600 and 1200 $\mathrm{ppm})$. Each sample of 5 fruits was soaked in a precise concentration for $1 \mathrm{~min}$ before or $30 \mathrm{~min}$ after their inoculation (Duamkhanmanee, 2008). There were two controls: inoculated and non-inoculated mango soaked only in sterile distillated water. Treated mango fruit was put in a cardboard box and then placed in the culture room at $28 \pm 2{ }^{\circ} \mathrm{C}$. The experiment was repeated twice.

\section{Disease evaluation}

After 48 hours, fruits inoculated were daily observed and the number of spots that produced lesions (Ns: symptoms) was noted. The incidence of disease (ID) or the lesions rate (Lr) for each treatment was calculated as followed:

$$
\mathbf{L}_{\mathbf{r}}(\%)=\frac{\mathbf{N}_{\mathbf{S}}}{\mathbf{N}_{\mathbf{T}}} \times \mathbf{1 0 0}
$$

$\mathbf{N}_{\mathrm{T}}$ : total number of inoculated spots

The evolution of lesions was also measured following two perpendiculars lines and the medium diameter of lesions (D) was calculated.

$D(\mathbf{m m})=(\mathbf{d} 1+\mathrm{d} 2) / 2 ;$

d1: lesion length following the largest diameter of the fruit

d2: lesion length following the smallest diameter of the fruit

The efficacy of each treatment (E) on the disease manifestation and evolution were then calculated according to the formula below (Mansour et al., 2006):

\section{$\mathbf{E}(\%)=[(\mathbf{T o}-\mathbf{T i}) / \mathbf{T o}] \mathbf{x} \mathbf{1 0 0}$}

To: lesion rate (lesion size) among control fruits

$\mathbf{T}_{\mathbf{i}}$ : lesion rate (lesion size) among treated fruits

\section{Physicochemical parameters evaluation}

The influence of the different doses of $O$. gratissimum oil on quality parameters of the fruit was evaluated at the $11^{\text {th }}$ day after incubation. The testing parameters are described below:

Mass loss: the mass of each mango fruit was measured by a Sartorius balance $( \pm 0.001 \mathrm{~g})$ before treatment $(\mathrm{A})$ and at the $11^{\text {th }}$ day of the experience (B), and mass loss was calculated as follows (Zhang et al., 2009): $\quad \mathbf{P}_{\mathbf{M}}(\%)=[(\mathbf{A}-\mathbf{B}) / \mathbf{A}] \mathbf{x} 100$

Fruit firmness: the firmness value of each fruit was determined using a crossbow type penetrometer. It evaluated the resistance inside the fruit to the penetration of the cylindrical instrument tip (length = $8 \mathrm{~mm}$, diameter $=3 \mathrm{~mm})\left(\mathrm{N}^{\prime} G a n z o u a\right.$ et al., 2010). Firmness values were measured at 4 spots (2 along the lateral sides, one on the dorsal surface and one at the front) and the average of the measurements was 
calculated for each fruit.

Titratable acidity: acidity was measured by titration with sodium hydroxide solution $0.1 \mathrm{~N}$ in the presence of phenolphthalein in $10 \mathrm{ml}$ of solution obtained from $3 \mathrm{~g}$ of each fruit pulp homogenized with $30 \mathrm{ml}$ distilled water and filtered. Results are expressed as (mean $\pm \mathrm{SE}$ ) $\mathrm{mEq} \cdot 10^{-2} \mathrm{~g}$ of fresh pulp,

pH: the $\mathrm{pH}$ of fruit juice was determined using a digital hand $\mathrm{pH}$-meter calibrated by $\mathrm{pH} 4$ and 7 buffer solutions.

Total soluble solids (TSS): Total soluble solids were determined by measuring the refractive index of the same juice with a digital hand refractometer (Atago $\mathrm{pr}-1)$ and the results were expressed as mean $\pm \mathrm{SE}$ ${ }^{\circ}$ Brix.

\section{Statistical Analysis}

Data were subjected to analysis of variance (ANOVA) using STATISTICA 7.1 software. Statistical significance was assessed at $p<0.05$ and Newman-Keuls's test was used to separate averages.

\section{RESULTS}

\section{Essential oils effect on the mycelial growth}

The sensitivity of $C$. gloeosporioides varied according to the concentrations used and incubation time. Monodora myristica oil had a low inhibitory activity on the fungal parasite. Respectively by the $1^{\text {st }}, 2^{\text {nd }}$ and $3^{\text {rd }}$ day after incubation, the dose of 2000 ppm reduced the mycelia growth by 90,50 , and $40 \%$ (figure 1). At concentrations of 100, 200, 500, and $1000 \mathrm{ppm}$, the essential oil of M. myristica reduced the mycelial growth less than $50 \%$. The $\mathrm{EC}_{50}$ and $\mathrm{EC}_{90}$ were respectively 13989 and $782268 \mathrm{ppm}$ (Table 1).

All the essential oils doses of Z. officinalis Roscoe rhizome used, caused a pathogenic reduction of mycelial growth (Figure 2). With the concentrations of 500, 1000, and $2000 \mathrm{ppm}, 50 \%$ of mycelial growth was obtained respectively on the $3^{\text {rd }}, 5^{\text {th }}$ and $12^{\text {th }}$ day. At the concentration of $2000 \mathrm{ppm}, 90 \%$ of reduction was observed on the $2^{\text {nd }}$ day after inoculation. The $\mathrm{EC}_{50}$ and $\mathrm{EC}_{90}$ were respectively 1335 and $9870 \mathrm{ppm}$ 7 days after incubation (Table 1).

The doses of $O$. gratissimum oil used had severely reduced mycelial growth of C. gloeosporioides (Figure 3). The inhibition rates varied from 34.40 to $100 \%$ according to the concentrations and time after incubation. At $8^{\text {th }}$ and $12^{\text {th }}$ days after incubation, more than $50 \%$ of reduction of mycelial growth was observed respectively at 100 and $200 \mathrm{ppm}$. With the doses of 1000 and 2000 ppm mycelial growth was totally inhibited. At the $7^{\text {th }}$ day, the $\mathrm{EC}_{50}$ and $\mathrm{EC}_{90}$ were respectively 10.30 and $447 \mathrm{ppm}$, and the MIC of mycelia growth was 1000 ppm (Table 1).
The transfer of explants at concentrations $1000 \mathrm{ppm}$ and $2000 \mathrm{ppm}$ showed the restart of $24.20 \%$ for the concentration of $1000 \mathrm{ppm}$ and nothing for the concentration $2000 \mathrm{ppm}$.

A high fungitoxic activity on the mycelial growth was expressed by the different doses of "Azoxystrombin" used (Figure 4). The reduction rates of mycelial growth obtained varied from 39.41 to $100 \%$ following the concentrations and the incubation time. The dose $1 \mathrm{ppm}$ totally inhibited mycelial growth at 6 days after incubation. The obtained $\mathrm{EC}_{50}$ and $\mathrm{EC}_{90}$ at the $7^{\text {th }}$ day was 0.0002 and $0.56 \mathrm{ppm}$ respectively (Table 1 ).

\section{Essential oils effect on spore germination}

The germination of $C$. gloeosporioides (Penz) spores was inhibited by the different essential oils and the synthetic fungicide used (Table 2). With M. myristica oil, the inhibition rate of spore germination varied from $22.3 \pm 8.8$ to $69.5 \pm 5.9 \%, 24$ hours after incubation (Table 2). The $\mathrm{EC}_{50}$ and $\mathrm{EC}_{90}$ concentrations of the spores germination were respectively $1258.9 \mathrm{ppm}$ and $12648.10 \mathrm{ppm}$ at 24 hours after incubation and no concentration had totally inhibited the germination (Table 1).

Regarding the essential oil of $O$. gratissimum, all the concentrations tested reduced the rate of spore germination more than 50\%. The doses 500, 1000, and $2000 \mathrm{ppm}$ reduced spore germination from 99.46 $\pm 0.5 \%$ to $100 \%$ (Table 2). The MIC for spore germination was $1000 \mathrm{ppm}$. The $\mathrm{EC}_{50}$ and $\mathrm{EC}_{90}$ of that oil were determined (Table 1). Concerning the essential oil of $Z$. officinalis, it also presented a high inhibitive effect on spore germination. All the dosages have had inhibitive activities varying from $54.09 \pm 6.24$ to $99.74 \pm 0.26 \%$ (Table 2). The $\mathrm{EC}_{50}$ and $\mathrm{EC}_{90}$ were respectively 91.20 and $891.25 \mathrm{ppm}$, and no MIC was determined at these concentrations. A high reduction in spore germination was also obtained with different concentrations of "Azoxystrombin". This activity was statistically superior to the oil of $M$. myristica and identical to those of $O$. gratissimum and Z. officinalis (Table 2). That product did not totally inhibit the spores germination at all of the different doses used (Table $1)$.

The two life stages of $C$. gloeosporioides were highly reduced by the different doses of the essential oils used. The essential oil of $O$. gratissimum was the most efficient on the two life stages. On the other side, the oil of M. myristica was the less efficient.

\section{In vivo activity of Ocimum gratissimum essential oil}

Curative capacity of Ocimum gratissimum essential oil 
Various doses of Ocimum gratissimum significantly reduced disease expression in treated fruits. Symptoms were observed on treated fruits at different dates. The average rates of the lesions obtained were spread into two statistically different groups ( $p=$ $0.0002)$ : the registered rates with the 150,600 , and $1200 \mathrm{ppm}$ treatments were $24 \pm 3.94 \% ; 24.67 \pm$ 4.02 and $20 \pm 3.12 \%$ respectively; this represents the first group (Table 3 ). The second group is represented by the rate obtained at $300 \mathrm{ppm}(38.67 \pm 4.82 \%)$.

As far as the progress of the disease is concerned, it was lower in the fruits treated during the experimental period. The mean size of the lesions produced fluctuated between $0.22 \pm 0.04$ and $0.46 \pm$ $0.07 \mathrm{~cm}$ (Table 3$)$.

All of the different doses used effectively reduced the incidence and progress of the disease on the treated fruit. The effectiveness of different doses in their ability to reduce the incidence of the disease on treated fruit varied from $48.76 \pm 13.08$ to $74.15 \pm$ $7.55 \%$. The $1200 \mathrm{ppm}$ solution was shown to be the best concentration with a rate of $74.15 \pm 7.55 \%$. That rate was significantly different from the rates of the other concentrations ( $p=0.0004) .1200 \mathrm{ppm}$ also significantly reduced the disease's progression.

\section{Protective capacity of Ocimum gratissimum essential oil}

All the doses of $O$. gratissimum oil used, significantly reduced the incidence of disease on the treated fruit. In fact, the medium rates of obtained lesions in treated fruit were inferior to that of the control (Table 4 ). Average values of $39.67 \pm 4.10 ; 39.73 \pm 5.03$ and $32.67 \pm 4.28 \%$ were respectively obtained at 300 , 600 , and $1200 \mathrm{ppm}$. All of these rates were statistically identical $(p=0.0585)$. The average rate $(48 \pm 4.59 \%)$ obtained at $150 \mathrm{ppm}$ was statistically different from that $(58.33 \pm 4.49 \%)$ of the control $(P$ $=0.0191)$. Disease progression was only slightly reduced. The measured lesion sizes varied from 0.47 $\pm 0.07 \mathrm{~cm}$ to $0.60 \pm 0.08 \mathrm{~cm}$. The mean sizes of the lesions measured were statistically identical with all of the treatments used $(p=0.1653$; Table 4$)$. The concentrations 600 and 1200 ppm were slightly more effective with on the one hand, respective reduction rates by $5.17 \pm 6.15$ and $51.99 \pm 06.51 \%$ of the incidence and on the other hand respective reduction rates of $38.06 \pm 8.55$ and $37.17 \pm 7.28 \%$ of the anthracnose progression (Table 4). Dose of $300 \mathrm{ppm}$ reduced the incidence of lesions by $35.86 \pm 6.07 \%$ and rate of disease progression by $21.04 \pm 9.19 \%$. This same dose was more effective with the curative technique than the protective one.

Influences of Ocimum gratissimum essential oil on physicochemical parameters

$>$ Mass loss: the rate of mass loss increased with the oil concentration (Table 5). Thus, the highest mass loss $(14.64 \pm 3.46 \%)$ in the treated fruit was observed at $1200 \mathrm{ppm}$. The loss of mass in fruit was similar among all the treatments used $(P=0.05377)$.

$>$ Firmness: The level of the fruit firmness was significantly reduced $(p=0.00004)$ at $300 \mathrm{ppm}$. However 150; 600 and 1200 ppm dosages didn't significantly influence the firmness of the fruit (Table 5).

Soluble sugar solids: The soluble sugar rate (TSS) was not significantly modified by the different dosages of $O$. gratissimum essential oil (Table 5). Therefore, TSS of treated fruits was statistically identical.

> Titratable acidity (TA): The titratable acidity content of the inoculated fruits showed no significant differences $(p>0.05)$ between treated fruits and control one (Table 5). Fruits treated with a concentration of $150 \mathrm{ppm}$ had the lowest TA value $\left(2.51 \pm 0.19 \mathrm{mEq} .10^{-2} \mathrm{~g}\right)$, while the fruits treated with the $300 \mathrm{ppm}$ solution gave the highest value $(4.25 \pm$ $0.41 \mathrm{mEq} .10^{-2} \mathrm{~g}$ ).

$>$ pH: Results for the $\mathrm{pH}$ of the fruit juice (Table 5) showed that, there were no significant modifications in the fruits treated with solution concentrations of 150, 600, and $1200 \mathrm{ppm}$ when compared to the control. However, the highest $\mathrm{pH}$ was recorded in the fruits treated with $300 \mathrm{ppm}$.

\section{DISCUSSION}

Among the natural compounds, essential oil offers a great potential as a biodegradable substance that has antimicrobial activity (Tripathi et al., 2008). The results of the present study showed that various concentrations of essential oils extracted from Ocimum gratissimum, Zingiber officinalis, and Monodora myristica inhibited linear growth and spores germination of $C$. gloeosporioides but, their efficacy varied. The essential oil of $O$. gratissimum performed best against $C$. gloeosporioides causing fungicidal effects on both mycelia growth and spore germination. Results are similar to reports of previous works which described $O$. gratissimum oil as an inhibitor of mycelial growth and spore germination in several postharvest pathogens, including C. gloeosporioides (Souza Júnior et al., 2009). They also found significant antifungal activity exhibited by $O$. gratissimum oil against others phytopathogens such us Aspergillus flavus, $A$. funigatus, Fusarium moniliforme and Deightoniella torulosa (N'guefack et al., 2004; Camara et al., 2007). On the contrary, Anaruma et al. (2010) revealed that the $O$. gratissimum oil from Brazil had a low antifungal activity against $C$. gloeosporioides (Penz.) \& Sacc. They found MIC of the oil at 2000 ppm, while that of this study was $1000 \mathrm{ppm}$. This difference of efficacy could be due to a difference in their chemical composition, which varies with the geographical location, time of harvest and the plant 
part collected (Matasyoh et al., 2007). In fact, the antifungal properties of essential oils are in relationship with their content of antimicrobial compounds (Dikbas et al., 2009). Farag et al. (1989) found that the inhibitory effect of the essential oils was mainly due to the chemical components within them. Seri-Kouassi (2004) reported a higher content of thymol $(43.1 \%)$ in the essential oil from $O$. gratissimum in Côte d'Ivoire compared to the $9.80 \%$ of thymol found in Brazil (Janine de Aquino et al., 2005). Many other studies reported that thymol is equipped with antifungal properties (Farag et al., 1989). In 1964, thymol was documented in the United States of America as a pesticide (Tripathi and Dubey, 2004). In fact, due to its dual nature, part alcohol and part lipid, it promoted the breakdown of fungal cell membranes (Kwazou et al., 2009). This may explain the higher inhibitory activity of $O$. gratissimum essential oils. Because of this, this essential oil could be recommended for a large-scale use within the scope of a biological control. Essential oils of $O$. gratissimum were found to be as effective as the synthetic fungicide Azoxystrombin. This synthetic fungicide product did not present any MIC on the two stages of life of $C$. gloeosporioides with the concentrations tested. This shows that the oil of $O$. gratissimum can be used instead of the synthetic fungicide in pathology control. The essential oils of $Z$. officinalis and M. myristica were less effective than the oil of $O$. gratissimum and neither of those two oils presented MIC on C. gloeosporioides. Concerning a comparison between the two, the essential oil of Z. officinalis, following the $\mathrm{EC}_{50}$ and $\mathrm{EC}_{90}$ detected, had an antifungal activity superior to that of M. myristica. The efficacy of Z. officinalis oil had been previously proven by work done by ElBaroty et al. (2010) where they found that, the oil of $Z$. officinalis highly inhibited the mycelial growth of four pathogenic fungi. The MIC they detected is at variance with the results found in this study. This difference in results may have been due to inherent differences in the parasites used. In their case, the pathogenic agents might have been more sensitive than ours. As far as the essential oils of M. myristica, were found to be less effective. These results were confirmed by Djeugap et al. (2009), who noticed that $M$. myristica oil had a lower antifungal activity against $C$. gloeosporioides.

In the present study, $O$. gratissimum essential oils effectively reduced the incidence and the evolution of disease on mango fruit as evidenced by the reduced infection rate and smaller lesion size seen on treated fruit compared to those of the control fruit. This result confirms the in vitro antifungal activity of $O$. gratissimum essential oils. The treatments after inoculation presented the lowest rates of infection, so it can be assumed that the essential oil of $O$. gratissimum was more effective as curative agent than as a preventive one. Because of its volatile nature, this essential oil would best be used as an eradication agent rather than a protection agent (Duamkhanmanee, 2008). The rates of infection obtained with the two highest doses are significantly very low. However, the inhibitive effect of $O$. gratissimum essential oil is much higher in vitro than in vivo. Similar findings were previously made by Hadizadeh et al. (2009). The quantity of oil and its necessary components to inhibit the microbic agents' growth is also higher on food than in a medium culture. That fact could be imputed to the interaction between the essential oil phenolitic compounds and the food matrix. Otherwise, this study also showed that the different doses of the essential oil did not significantly influence the firmness of the fruits. This suggests that they did not act on the activity or did not favor the synthesis of the hydrolyzing enzymes. Similar results were reported by Maqbool et al. (2010), who has evaluated Cinnamon spp essential oil effect on the post-harvest incidence of the anthracnose and the quality of bananas during the storage. These authors discovered that the different concentrations of the tested oils did not impact the firmness of the treated bananas. On the contrary, Raafat et al. (2012) reported that essential oils of Cuminum cyminum L., Cymbopogon citratus L. have caused an increase of treated strawberries firmness. This difference could be explained by the vegetable material. Moreover, the different doses of the oil of $O$. gratissimum also did not significantly influence the rate of TSS in the treated fruits and this result was similar to those reported by Maqbool et al. (2010). Concerning the mass loss, the dose of $1200 \mathrm{ppm}$ of $O$. gratissimum brought out a significant loss of the treated fruits mass. This loss could be due to an increase in transpiration. On the contrary, Espitia et al. (2012) reported that essential oil of Origanum vulgare, Cinnamomum zeylanicum and of Cymbopogon flexuosus caused no significant loss of mass between treated pawpaw and controls. The essential oils of $O$. gratissimum also provoked a slight variation in the acidic titration. A dose 300 ppm favored a significant increase of the $\mathrm{pH}$ of the treated fruit, but with the other treatments and control there was not significant acidity change in fruit. In similar study, Tzortzakis (2007) reported that the vapor of Eucalyptus globulus L. and Cinnamomum zeylanicum, Blume, essential oils did not have a significant effect on the acidic quality in treated tomatoes and strawberries. These results contrast with the ones reported by Mohammadi and Aminifard (2012). They noticed that the $\mathrm{pH}$ value of peach fruit treated with essential oils was inferior to that of control fruit.

\section{CONCLUSION}

The present study demonstrated a high antifungal activity of $O$. gratissimum essential oils against $C$. 
gloeosporioides (penz.) Penz \& Sacc.M. myristica essential oils were also shown to have very brief activity at high concentrations. Finally, the dose 1200 ppm of $O$. gratissimum essential oils in emulsion assured a high inhibition of development of the anthracnose symptoms and their progress in artificially inoculated mangoes. Moreover, it did not alter the quality parameters of treated mangoes. So the essential oil of $O$. gratissimum can be used as an alternative way to control the postharvest anthracnose of mango fruit. Further studies on its stability as food preservative and on their use in combination with modified atmosphere packaging are recommended.

\section{REFERENCES}

1) Abd-AllA M.A. \& Haggag W. M. (2010). New Safe Methods for Controlling Anthracnose Disease of Mango (Mangifera indica L.) Fruits Caused by Colletotrichum gloeosporioides (Penz.). J. Am. Sci. 6 (8): 361-367.

2) Anaruma N.D., Schimidt F.L., Teixeira Duarte M.C., Figueira G.M., Delarmelina C., Benato L.A, Sartoratto A. (2010). Control of Colletotrichum gloeosporioides (Penz.) Sacc. In yellow passion fruit using Cymbopogon citratus essential oil. Braz. J. Microbiol.41 (1): 66 -73

3) Barnett, H. L. and B. B. Hunter. (1972). Illustrated Genera of Imperfect Fungi. Mineapolis : Burgress Publishing Company, Minneapolis MN, 241p

4) Bouigoumane I., Selmaoui K., Ouazzani T. A. et Allal D. (2008). Efficacité in vitro et in vivo de différents fongicides sur le développement de la pourriture des poires dans la chambre froide d'Oulmès (Maroc). Rev. Biol. Biotech. 2 (7): 37- 47

5) Camara B, Koné D, Kanko C, Anno A. et Aké S. (2007). Activité antifongique des huiles essentielles de Ocimum gratissimum L., de Monodora myristica (Gaaertn) Dunal et de deux produits de synthèses (Impulse et Folicur) sur la croissance mycélienne et la production de spore in vitro de Deightoniella torulosa (Syd.) Ellis. Rev. Ivoire Sci. Technol. 09: 187-201

6) Djeugap J.-F., Kuite J.-R and Fontem D.-A. (2009). Etat sanitaire post-récolte de la mangue commercialisée dans la ville de Dschang et efficacité in vitro des huiles essentielles contre Colletotrichum gloeosporioides Penz., agent causal de l'anthracnose, Communication, AFPP-9 ${ }^{\text {ème }}$ Conférence internationale sur les maladies des plantes, Tours 8 et 9 Décembre 2009, 571-578.

7) Dikbas N., Kotan R, Dadasoglu E., Karagöz K. \& Çakmakcı R. (2009). Correlation between Major Constituents and Antibacterial Activities of Some Plant Essential Oils against Some Pathogenic Bacteria. Turkish J. Sc. \& Tech. 4 (1): 57-64

8) Duamkhanmanee, R. (2008). Natural essential oils from lemon grass (Cymbopogon citratus) to control postharvest anthracnose of mango fruit. Int. J. Biotechnol.10 (1): 104-108

9) El-Baroty G.S., Abd El-Baky H. H., Farag R. S \& Saleh M. A. (2010). Characterization of antioxidant and antimicrobial compounds of cinnamon and ginger essential oils. Afr. J. Biochem. Res. 4(6): 167-174

10) Espitia, P. J. P., Soares, N. de F. F., Botti, L. C. M., Ramos de Melo N., Pereira, O. L., et Silva W. A. (2012). Assessment of the efficiency of essential oils in the preservation of postharvest papaya in an antimicrobial packaging system. Braz. J. Food Technol., Campinas 15(4): 307-316.

11) Farag R.S., Daw Z.Y. and Abo-Raya S.H. (1989). Influence of some spice essential oils on Aspergillus parasiticus growth and production of aflatoxins in a synthetic medium. J. of Food Sci. 54: 74-76.

12) Feng W \& Zheng X. (2007). Essential oils to control Alternaria alternata in vitro and in vivo. Food control. 18: 1126-1130
13) FIRCA (2008). Rapport annuel du Fonds Interprofessionnel pour la Recherche et le Conseil Agricoles, $12 \mathrm{p}$.

14) Gerbaud P. (2011). La Mangue. «Panorama statistique mondial » Les dossiers du mois de Fruitrop, $\mathrm{N}^{\circ} 186$; Février 2011, 64p.

15) Hadizadeh I., Peivastegan B \& Hamzehzarghani H. (2009). Antifungal Activity of essential Oils from Some Medicinal Plants of Iran against Alternaria alternata. Am. J. Applied Sci. 6 (5): 857-861

16) Janine de Aquino L.s, Xisto S. P., Orionalda de Fátima L. F., José R. de P., Pedro H. F., Lúcia K. H. S., Aline de Aquino L. \& Maria do Rosário R. S. (2005). Antifungal activity from Ocimum gratissimum L. towards Cryptococcus neoformans. Mem. Inst. Oswaldo Cruz. 100 (1): 55-58

17) Kwazou N.L., Jagzed D. P. M., Tatsadjieu N. L., Sameza M. L., Ndongson D. B., Amvam Z. P.H. \& Menut C. (2009). Propriétés antifongiques des huiles essentielles de quelques plantes du genre Aframomum du Cameroun contre Aspergillus flavus. Cameroon J. Experimental Biol. 05 (1): 44 - 51

18) Mansour F.S. Abd-El-Aziz, S.A. \& Helal G.A. (2006). Effect of fruit heat treatment In three mango varieties on incidence of postharvest fungal disease. J. Plant Pathol.88 (2):141-148

19) Maqbool M., Asgar A. \& Alderson P. G. (2010). Effect of Cinnamon Oil on Incidence of Anthracnose Disease and Postharvest Quality of Bananas during Storage. Int. J. Agric. Biol.12: 516-520

20) Matasyoh L. G., Matasyoh J.C., Wachira F. N., Kinyua M. G., Muigai Thairu A. W. \& Mukiama T. K. (2007). Variation in the antimicrobial activity of essential oils of Ocimum gratissimum L. from different populations of Kenya. Afr. Crop Sci. Conference Proceedings.8: 1745-1750

21) Mohammadi S. \& Aminifard M. H. (2012). Effect of Essential Oils on Postharvest Decay and Some Quality Factors of Peach (Prunus persica var. Redhaven) J. Biol. Envir. Sci. 6 (17):147153

22) N'Ganzoua K.R., Camara B. \& Dick E. (2010). Evaluation des changements physico-chimiques caractérisant le mûrissement au cours de l'entreposage de trois variétés de bananes Musa spp. (AAB, cv. Corne1; AAA, cv. Poyo et AA, cv. Figue Sucrée), Sci. Nat.7 (2): 155-163

23) Nguefack J., Leth V., Amvam Zollo P.H. \& Mathur S.B. (2004). Evaluation of five essential oils from aromatic plants of Cameroon for controlling food spoilage and mycotoxin producing fungi. Int. J. Food Microbiol. 94 (3): 329-334.

24) Raafat S. M, Abou-Zaid, M.I., Aly A.Z \& Tohamy M.R.A. (2012). Safety control of strawberry fruits gray mold fungus by plant volatile oils. Zagazig J. Agric. Res.39 (2):181-187

25) Remmal A., Bouchikhi T., Rhayour K., Ettayebi M.\& Tantaoui-Elaraki A (1993). Improved method for determination of antimicrobial activity of essential oils in agar medium. J. Essent. Oils Res. 5 (2):179-184.

26) Satrani B., Farah A., Fechtal M., Talbi M., Blaghen M., et Chaouch A. (2001). Composition chimique et activité antimicrobienne des huiles essentielles de Satureja calamintha et Satureja alpina du Maroc. Ann. Falsif. Expert. Chim. 94 (956): 241-250

27) Serghat S., Mouria A., Ouazzani Touhami A., Badoc A. \& Douira A. (2004). Effet de quelques fongicides sur le développement in vitro de Pyricularia grisea et Helminthosporium oryzae. Bull. Soc.Pharm. Bordeaux, 143: 7 18.

28) Seri-Kouassi B. P. (2004). Entomofaune du niébé en culture, bio-écologie et gestion des Populations de Callosobruchus maculatus FAB. (Coleoptera: Bruchidae) à l'aide d'huiles essentielles comme bio-pesticides dans les stocks de cette denrée en Côte d'Ivoire. Thèse de Doctorat d'Etat, Université de Cocody-Abj, 198p.

29) Sivakumar D. and Bautista-Baños (2014). A review on the use of essential oils for postharvest decay control and maintenance of fruit quality during storage. Crop Protection 64: 27-37

30) Souza Júnior I.T., Pereira S. N. L. and Martins E. R. (2009). Efeito fungitóxico de óleos essenciais sobre Colletotrichum gloeosporioides, isolado do maracujazeiro amarelo. Revista Biotemas, 22 (3): 77-83 
Antifungal Activity of Essential Oils Extracted from Monodora myristica (Gaertn), Ocimum gratissimum L. and Zingiber officinalis Roscoe on Post-harvest Anthracnose of Mango Fruit (Mangifera indica L.) Variety Kent in Côte d'Ivoire

31) Tripathi P \& Dubey N.K. (2004). Exploitation of natural product as an alternative strategy to control postharvest fungal rotting of fruit and vegetables. Postharvest Biol. Technol.32: 235-245

32) Tripathi P., Dubey N.K. \& Shukla A. K. (2008). Use of essential oils as post-harvest botanical fungicides in the management of grey mould of grapes caused by botrytis cinerea. World J. Microbiol Biotechnol. 24: 39-46.
33) Tzortzakis N.G. (2007). Maintaining postharvest quality of fresh produce with volatile Emerg. Technol. 8: 111-116.

34) Zhang H., Wang L., Ma L., Dong Y., Jiang S., Xu B. \& Zheng X. (2009). Biocontrol of major postharvest pathogens on apple using Rhodotorula glutinis and its effects on porstharvest quality parameters. Biological control 48: 79-83

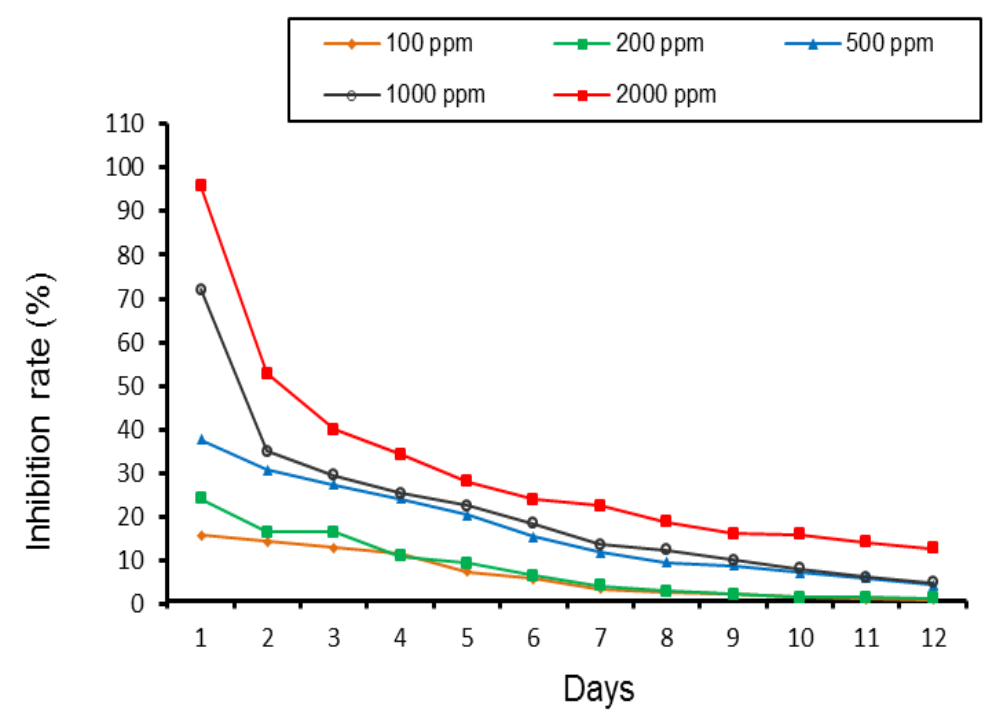

Figure 1. Inhibitory Effect of Monodora myristica essential oil on mycelia growth of Colletotrichum gloeosporioides
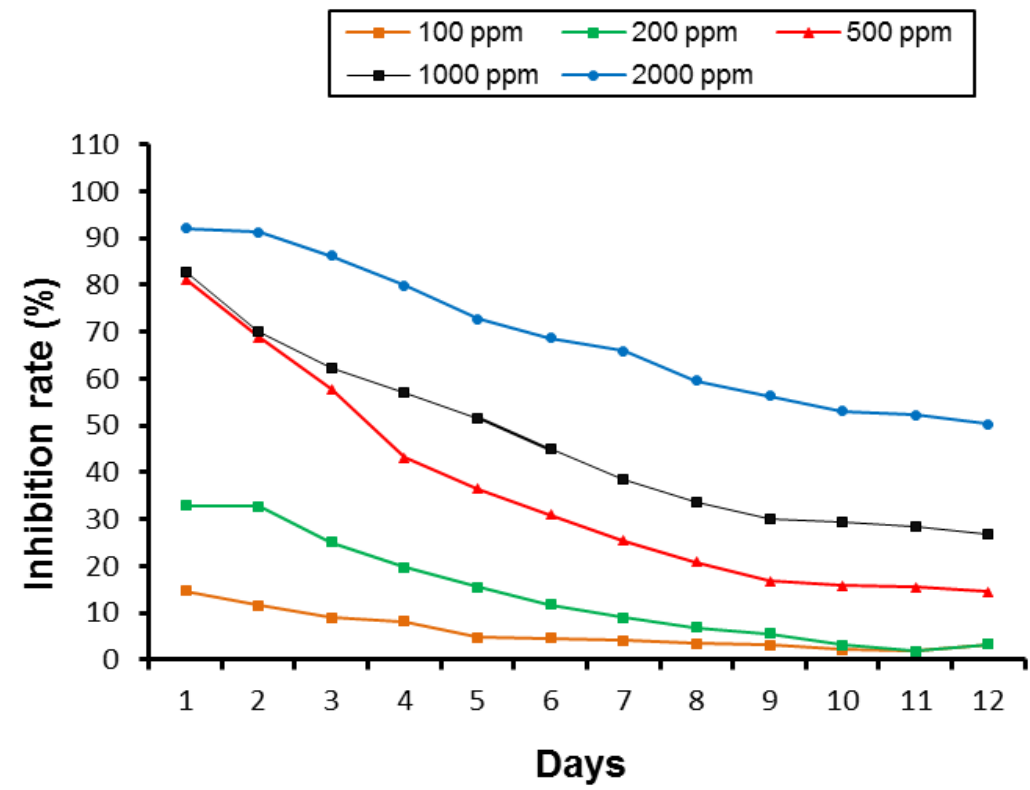

Figure 2. Inhibitory Effect of Zingiber officinalis essential oil on mycelia growth of Colletotrichum gloeosporioides 
Antifungal Activity of Essential Oils Extracted from Monodora myristica (Gaertn), Ocimum gratissimum L. and Zingiber officinalis Roscoe on Post-harvest Anthracnose of Mango Fruit (Mangifera indica L.) Variety Kent in Côte d'Ivoire

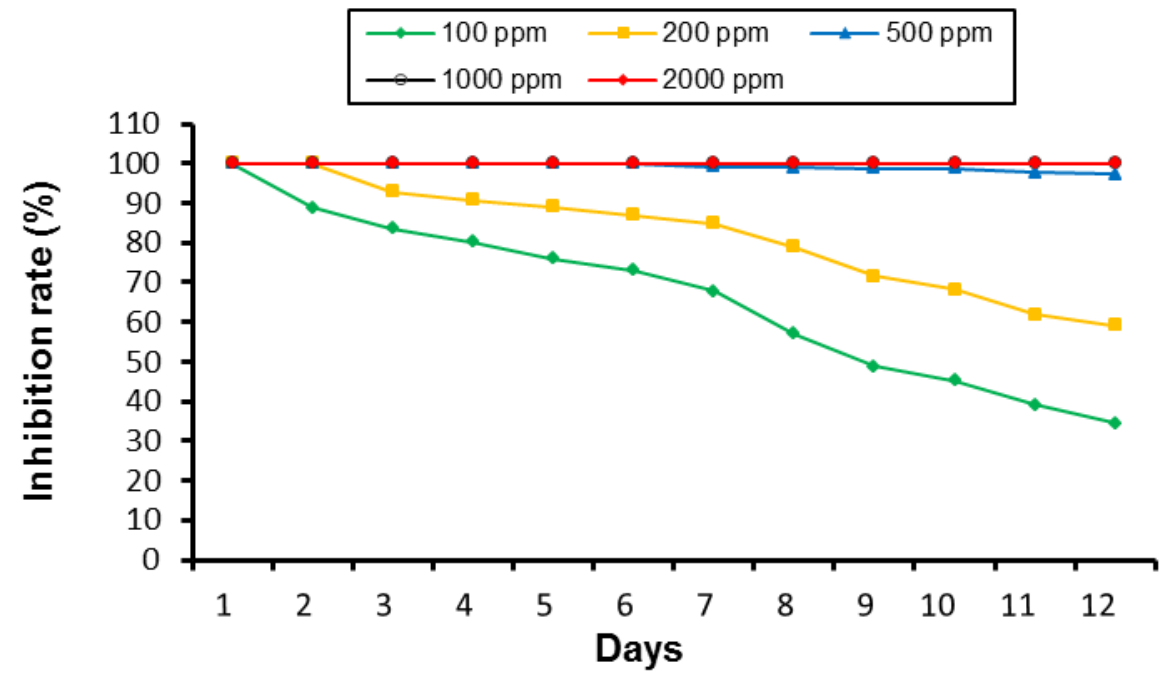

Figure 3. Inhibitory effect of Ocimum gratissimum essential oil on mycelial growth of Colletotrichum gloeosporioides

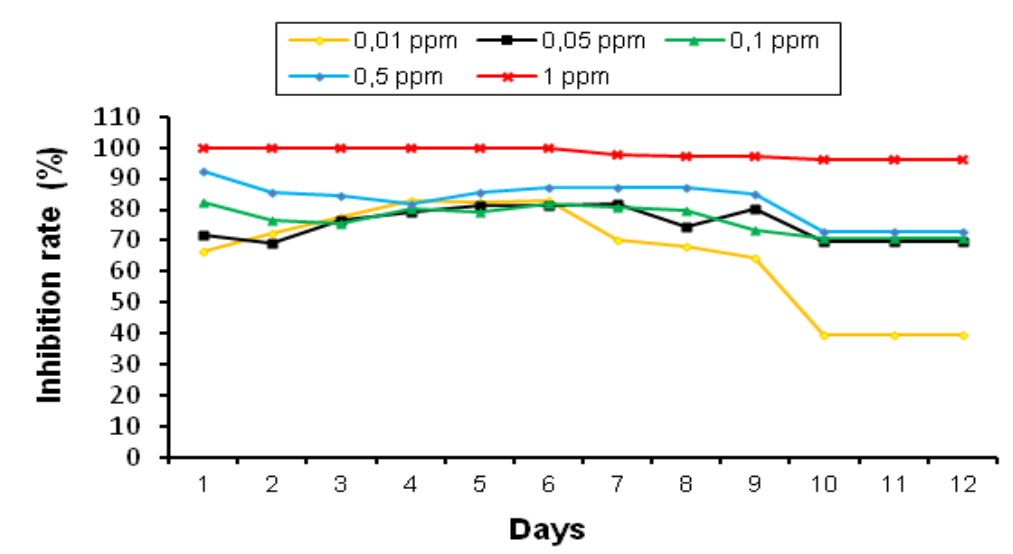

Figure 4. Inhibitory effect of synthetic fungicide «Azoxistrombin» on mycelial growth of Colletotrichum gloeosporioides

Table 1: Effective dose for 50 and $90 \%$ inhibition $\left(\mathrm{EC}_{50}, \mathrm{EC}_{90}\right)$ and Minimum inhibitory concentration (MIC) of 3 essential oils and synthetic fungicide against Colletotrichum gloeosporioides respectively after 7 days and 24 hours of incubation

\begin{tabular}{|c|c|c|c|c|c|c|}
\hline \multirow{2}{*}{$\begin{array}{l}\text { Antifugal parameters } \\
\text { Products }\end{array}$} & \multicolumn{3}{|c|}{ Mycelial growth } & \multicolumn{3}{|c|}{ Spore germination } \\
\hline & $\mathrm{EC}_{50}$ & $\mathrm{EC}_{90}$ & $\mathrm{MIC}$ & $\mathrm{EC}_{50}$ & $\mathrm{EC}_{90}$ & MIC \\
\hline Monodora myristica & 13989 a & 782267 a & - & $1258.9 \mathrm{a}$ & $12648 \mathrm{a}$ & - \\
\hline Ocimum gratissimum & $10.30 \mathrm{c}$ & $447 \mathrm{c}$ & $1000 \mathrm{a}$ & $81.13 \mathrm{~b}$ & $446.7 \mathrm{~b}$ & $1000 \mathrm{a}$ \\
\hline Zingiber officinalis & $1335 \mathrm{~b}$ & $9870 \mathrm{~b}$ & - & $91.20 \mathrm{~b}$ & $891.3 \mathrm{c}$ & - \\
\hline Azoxystrombin & $0.0002 \mathrm{~d}$ & $0.41 \mathrm{~d}$ & - & $0.0003 \mathrm{c}$ & $0.25 \mathrm{~d}$ & - \\
\hline
\end{tabular}

Averages followed by the same letter within each column did not differ significantly at $P \leq 0.05$ according to

Newman Keuls Test. (- No concentration) 
Antifungal Activity of Essential Oils Extracted from Monodora myristica (Gaertn), Ocimum gratissimum L. and Zingiber officinalis Roscoe on Post-harvest Anthracnose of Mango Fruit (Mangifera indica L.) Variety Kent in Côte d'Ivoire

Table 2. Effect of different concentration of essential oils and synthetic fungicide on spore germination of Colletotrichum gloeosporioides in vitro after 24 hours of incubation.

\begin{tabular}{|c|c|c|c|c|}
\hline & \multicolumn{3}{|c|}{ Essential oils } & \multirow{2}{*}{$\begin{array}{c}\text { Synthetic fungicide } \\
\text { Azoxistrombin }\end{array}$} \\
\hline & $\begin{array}{l}\text { Monodora } \\
\text { myristica }\end{array}$ & $\begin{array}{l}\text { Ocimum } \\
\text { gratissimum }\end{array}$ & $\begin{array}{l}\text { Zingiber } \\
\text { officinalis }\end{array}$ & \\
\hline $100(\mathbf{0 . 0 1})$ & $22.3 \pm 8.8 \mathrm{~d}$ & $68.7 \pm 4.1 \mathrm{~b}$ & $54.1 \pm 6.2 \mathrm{bc}$ & $71.7 \pm 6.8 \mathrm{ab}$ \\
\hline $200(\mathbf{0 . 0 5})$ & $33.4 \pm 9.6 \mathrm{c}$ & $91.2 \pm 1.8 \mathrm{a}$ & $59.4 \pm 6.1 \mathrm{~b}$ & $78.3 \pm 4.1 \mathrm{ab}$ \\
\hline $500(\mathbf{0 . 1})$ & $40.6 \pm 7.6 \mathrm{~d}$ & $99.9 \pm 0.1 \mathrm{a}$ & $71.2 \pm 5.0 \mathrm{bc}$ & $86.3 \pm 2.8 \mathrm{ab}$ \\
\hline $1000(\mathbf{0 . 5})$ & $48.2 \pm 6.1 \mathrm{~b}$ & $100 \pm 0.0 \mathrm{a}$ & $95.5 \pm 1.4 \mathrm{a}$ & $94.2 \pm 1.5 \mathrm{a}$ \\
\hline $2000(\mathbf{1})$ & $69.5 \pm 5.9 \mathrm{~b}$ & $100 \pm 0.0 \mathrm{a}$ & $99.7 \pm 0.3 \mathrm{a}$ & $98.1 \pm 0.7 a$ \\
\hline \multicolumn{5}{|c|}{$\begin{array}{l}\text { Averages followed by the same letter within each column did not differ significantly at } P \leq 0.05 \text { according } \\
\text { Newman Keuls Test }\end{array}$} \\
\hline $\begin{array}{l}\text { Treatments } \\
\text { (ppm) }\end{array}$ & Infection rate $(\%)$ & Effectiveness & Lesions size $(\mathrm{cm})$ & Effectiveness \\
\hline 00 & $58.33 \pm 4.49$ a & & $0.64 \pm 0.08 \mathrm{a}$ & \\
\hline 150 & $24.00 \pm 3.94 \mathrm{c}$ & $64.97 \pm 9.26 \mathrm{~b}$ & $0.31 \pm 0.06 \mathrm{~cd}$ & $43.16 \pm 18.17 b c$ \\
\hline 300 & $38.67 \pm 4.82 b$ & $48.76 \pm 13.08 \mathrm{c}$ & $0.46 \pm 0.07 \mathrm{~b}$ & $47.97 \pm 13.45 b$ \\
\hline 600 & $24.67 \pm 4.02 \mathrm{c}$ & $63.75 \pm 7.38 \mathrm{~b}$ & $0.33 \pm 0.06 \mathrm{c}$ & $40.46 \pm 17.81 \mathrm{c}$ \\
\hline 1200 & $20.00 \pm 3.12 \mathrm{c}$ & $74.15 \pm 7.55 \mathrm{a}$ & $0.22 \pm 0.04 \mathrm{~d}$ & $76.63 \pm 6.93 \mathrm{a}$ \\
\hline
\end{tabular}

Averages followed by the same letter within each column did not differ significantly at $P \leq 0.05$ according to Newman Keuls Test

Table 4: Effectiveness of the essential oil of Ocimum gratissimum on the development and anthracnose symptoms evolution in Kent mangoes variety in treatment before inoculation (preventive).

\begin{tabular}{ccccc}
\hline $\begin{array}{c}\text { Treatments } \\
(\mathrm{ppm})\end{array}$ & \multicolumn{1}{c}{ Infection rate $(\%)$} & Effectiveness & Lesions size $(\mathrm{cm})$ & Effectiveness \\
\hline 00 & $58.33 \pm 4.49 \mathrm{a}$ & $0.64 \pm 0.08 \mathrm{a}$ & \\
150 & $48 \pm 4.59 \mathrm{~b}$ & $37.78 \pm 8.91 \mathrm{a}$ & $0.60 \pm 0.07 \mathrm{ab}$ & $23.20 \pm 9.12 \mathrm{a}$ \\
300 & $39.67 \pm 4.10 \mathrm{bc}$ & $35.86 \pm 6.07 \mathrm{a}$ & $0.55 \pm 0.06 \mathrm{ab}$ & $21.04 \pm 9.19 \mathrm{a}$ \\
600 & $39.73 \pm 5.03 \mathrm{bc}$ & $50.17 \pm 6.15 \mathrm{a}$ & $0.50 \pm 0.06 \mathrm{~b}$ & $38.16 \pm 8.55 \mathrm{a}$ \\
1200 & $32.67 \pm 4.28 \mathrm{c}$ & $51.99 \pm 6.51 \mathrm{a}$ & $0.47 \pm 0.07 \mathrm{~b}$ & $37.17 \pm 7.23 \mathrm{a}$ \\
\hline
\end{tabular}

Averages followed by the same letter within each column did not differ significantly at $P \leq 0.05$ according to Newman Keuls Test 
Antifungal Activity of Essential Oils Extracted from Monodora myristica (Gaertn), Ocimum gratissimum L. and Zingiber officinalis Roscoe on Post-harvest Anthracnose of Mango Fruit (Mangifera indica L.) Variety Kent in Côte d'Ivoire

Table 5. Effect of Ocimum gratissimum essential oil on some quality parameters of Kent mangoes variety

\begin{tabular}{cccccc}
\hline $\begin{array}{c}\text { Treatment } \\
(\mathrm{ppm})\end{array}$ & Mass loss $(\%)$ & Firmness $(\mathrm{Kg})$ & $\begin{array}{c}\text { Soluble sugar rate } \\
\left({ }^{\circ} \text { Brix }\right)\end{array}$ & $\begin{array}{c}\text { Acidic Titration } \\
\mathrm{mEq} .10-^{2} \mathrm{~g}\end{array}$ & $\mathrm{pH}$ \\
Too & $9.63 \pm 1.04 \mathrm{~b}$ & $2.46 \pm 0.38 \mathrm{a}$ & $1.32 \pm 0.12 \mathrm{~b}$ & $5.24 \pm 0.92 \mathrm{a}$ & $4.44 \pm 0.10 \mathrm{~b}$ \\
00 & $7.98 \pm 0.15 \mathrm{~b}$ & $2.35 \pm 0.28 \mathrm{a}$ & $1.69 \pm 0.12 \mathrm{a}$ & $2.73 \pm 0.23 \mathrm{~b}$ & $4.43 \pm 0.12 \mathrm{~b}$ \\
150 & $7.75 \pm 0.73 \mathrm{~b}$ & $2.44 \pm 0.18 \mathrm{a}$ & $1.70 \pm 0.12 \mathrm{a}$ & $2.51 \pm 0.19 \mathrm{~b}$ & $5.02 \pm 0.31 \mathrm{ab}$ \\
300 & $9.60 \pm 1.33 \mathrm{~b}$ & $1.09 \pm 0.22 \mathrm{~b}$ & $1.84 \pm 0.07 \mathrm{a}$ & $4.25 \pm 0.41 \mathrm{ab}$ & $5.55 \pm 0.14 \mathrm{a}$ \\
600 & $12.27 \pm 1.75 \mathrm{ab}$ & $2.45 \pm 0.24 \mathrm{a}$ & $1.65 \pm 0.08 \mathrm{a}$ & $3.80 \pm 0.45 \mathrm{ab}$ & $4.50 \pm 0.13 \mathrm{~b}$ \\
1200 & $14.64 \pm 3.46 \mathrm{a}$ & $2.33 \pm 0.16 \mathrm{a}$ & $1.65 \pm 0.07 \mathrm{a}$ & $3.54 \pm 0.54 \mathrm{~b}$ & $4.30 \pm 0.15 \mathrm{~b}$
\end{tabular}

Averages followed by the same letter within each column did not differ significantly at $P \leq 0.05$ according to Newman Keuls Test. (Too: No inoculated and no treated fruits) 